\title{
急性冠症候群における標準四肢誘導心電図 $\mathrm{a} V \mathrm{R}$ 誘導の $\mathrm{ST}$ 上昇の意義に関する研究
}

酒井俊太* 高野照夫* 高山守正* 早川弘一*

急性冠症候群発作時の標準四肢誘導心電図 $\mathrm{V} V R$ R ST 上昇の意義について検討した. 不安定狭心症 (UAP : 220 例) は発作時, 急性心筋梗塞 (AMI：485 例) は収容時所見で それぞれ $\mathrm{aVR}$ R S T 上昇群, 非上昇群の 4 群に分け, 臨床所見, 冠動脈障害枝数を比較 した. UAP でST 上昇群の 3 枝/左主幹部病変例の占める比率は $49 \%$, 非上昇群 $3 \%$ で, ST上昇群で有意に多かった $(p<0.01)$. AMl でも $S T$ 上昇群の 3 枝・左主幹部病 変例の占める比率は $59 \%$, 非上昇群 $6 \%$ で同様な差を認めた $(p<0.01)$. さらにST上 昇群はいずれも「左前下行枝十回旋枝」の組み合わせが有意に多かった $(P<0.01)$. また Killip 分類III ・ IV 群が ST上昇群 $45 \%$, 非上昇群 $13 \%$ で, 重症心機能低下例はST上昇 群に有意に多かった $(D<0.01)$. 急性冠症候群の $a \vee R$ 誘導 $S T$ 上昇は多枝冠障害 (左冠 動脈主体）とAMI 例で重症ポンプ不全の存在を示す。

(心電図 18 : No.6, 849〜857, 1998)

\section{I .はじめに}

急性心筋梗塞発症早期の死亡率は高く, その原因 は重症ポンプ不全, 致死的不整脈, 突然死であり,

\begin{tabular}{|ll|}
\hline Key Words & $\bullet \mathrm{aVR}$ 誘導 \\
& $\bullet$ 急性冠症候群 \\
& $\bullet \mathrm{ST}$ 上昇 \\
& $\bullet$ 不安定狭心症 \\
& $\bullet$ 急性心筋梗塞
\end{tabular}

$*$ 日本医科大学第一内科 . 集中治療室

（テ 113-8603 東京都文京区千駄木 1-1-5）
かかる例の冠動脈病変は左主幹部を含めた多枝病変 例が多いとされている1).一方, 不安定狭心症の予後 は悪く, 診断から 8 カ月以内に $21 \%$ が急性心筋梗塞 に移行し，そのうち $41 \%$ が死亡すると述べられてい $3^{2)}$. 急性心筋梗塞や不安定狭心症の急性冠症候群 ${ }^{3)}$ では冠動脈障害枝数が予後を左右し, 左主幹部病変, 3 枝病変例では 1,2 枝病変に比べ予後が著しく悪 いと報告されている4 7).したがって発症早期に冠動 脈の病変枝数や障害程度を臨床的に推定することが 重要である.

ところで心内膜下梗塞の診断には標準四肢誘導心

Clinical study on the significance of ECG ST-segment elevation in lead aVR in acute coronary syndrome. Shunta Sakai, Teruo Takano, Morimasa Takayama, Hirokazu Hayakawa

1998 年 3 月 19 日 原稿受領 $/ 1998$ 年 6 月 20 日 掲載承認 
電図診断における $\mathrm{aVR}$ 誘導の $\mathrm{ST}$ 上昇と胸部誘導 陰性 $\mathrm{T}$ を認めることが必要である ${ }^{8 \sim 10)}$ 。心内膜下梗 塞は梗塞病変が非貫壁性でかつ左心室内側の 3 分の 1 に円周性に存在する心筋梗塞と定義され, 冠動脈 造影所見は多枝障害が多いとされる ${ }^{11}$.しかし,一般 の貫壁性梗塞や以上の心内膜下梗塞と同様の虚血の 局在を示す不安定狭心症などの急性冠症候群におい て, $\mathrm{aVR}$ 誘導がどのような変化を示すかについての 研究はない. 本論文では, $\mathrm{aVR}$ 誘導の変化に着目 し, その臨床的意義を調べ, 冠動脈障害枝数や心機 能重症度を推定できるか否かを検討した。

\section{II. 対象と方法}

対象は, 日本医科大学集中治療室に収容された （1993 年 10 月より 1997 年 3 月）不安定狭心症 (UAP) 連続 271 例と急性心笳梗塞 (AMI) 連続 646 例中, 冠動脈造影を施行し得たそれぞれ 230 例, 493 例である.UAP は胸痛発作時, AMI は収容時 ECG の $\mathrm{aVR}$ 誘導に着目し， $0.1 \mathrm{mV}$ 以上の $\mathrm{ST}$ 上昇の有 無によって,

1) UAP 上昇群

2 ) UAP 非上昇群

3 ) AMI 上昇群

4) AMI 非上昇群

の 4 群に分類した。

なお, UAP は胸痛発作時 ECG にて $0.1 \mathrm{mV}$ の一 過性 ST 低下を認め, 異常 $\mathrm{Q}$ 波を認めず，かつ心筋 逸脱酵素 CPK または $\mathrm{CPK}-\mathrm{MB}$ が正常值上限の 2 倍未満のものとし，分析には Braunwald の分類 ${ }^{12)}$ を用いた。

また AMI は，

1) 胸痛が 20 分以上持続し,

2 ) ECG で異常 Q 波, ST 上昇と対側の ST 下降 の心筋梗塞所見を示し，

3 ) $\mathrm{CPK}$ または $\mathrm{CPK}-\mathrm{MB}$ 值が正常上限の 2 倍 以上に上昇したもの

とした。

ECG の ST-T 偏位は基準線として TP 線を用
(13), J ポイントから $60 \mathrm{msec}$ の ST 偏位が $0.1 \mathrm{mV}$ 以上の場合を有意な下降，上昇とした。

各群において下記の項目を比較検討した。

1 ）患者背景・臨床所見および経過

2 ) 胸痛発作時の $\mathrm{aVR}$ 誘導以外の ST 偏位を認 めた誘導数 $(n-S T)$

$3) \mathrm{aVR}$ 誘導を除いたST 偏位の絶対值総量 $(\Sigma-$ $\mathrm{ST}$ )

4 ) 冠動脈造影における主要冠動脈有意狭窄枝数 冠動脈造影は, 全例で収容後 7 日以内にジャドキ ンス法にて施行し, AHA 狭窄度分類により $90 \%$ 以 上の狭窄を認めたものを有意とした，左室駆出率は， 経胸壁心エコー図法を用いて，修正シンプソン法に より算出した ${ }^{14)}$.

なお，ST 変化の評価を困難とさせる左脚ブロッ ク例, 左室肥大例（心筋壁厚が $12 \mathrm{~mm}$ 以上のも の), ジギタリス薬使用例, 冠動脈バイパス術既往例 は, 本検討から除外した。

測定値は平均土標準偏差で示し, 統計学的解析は, 二群間の比較に un-paired $\mathrm{t}$ 検定, $\mathrm{x}^{2}$ 検定を, 相対危 険度に Cox 回帰分析のハザード比を用いた。いずれ も $\mathrm{P}<0.05$ を有意とした。感度は真陽性／（真陽 性十偽陰性), 特異度は真陰性／(真陰性＋偽陽 性)，的中率は（真陽性十真陰性）／総和，陽性予測 率は真陽性 /(真陽性＋偽陽性), 陰性予測率は真陰 性／（真陰性十偽陰性）とした。

\section{III. 結 果}

冠動脈造影を施行し得た不安定狭心症 230 例中除 外項目例 10 例 ( $4 \%$ ) を除く 220 例と急性心筋梗塞 例 493 例中除外項目例 8 例（2\%）を除く 485 例に ついて aVRのST上昇の有無により以下の 4 群に 分類された。

1) UAP 上昇群：70 例

2 ) UAP 非上昇群 : 150 例

3) AMI 上昇群 : 72 例

4) AMI 非上昇群 : 413 例

\section{1. 不安定狭心症の成績}


1 ）患者背景・臨床所見および経過

表 1 のように ST 上昇群の年齢は, 非上昇群に比 べ有意に高齢であった $(\mathrm{P}<0.01)$ が，性，冠危険因 子，心筋梗塞既往の有無打よび Braunwald 分類に おける発症様式・原因については両群間に有意差は なかった。

2 ) 胸痛発作出現時の $\mathrm{n}-\mathrm{ST}$ と $\Sigma-\mathrm{ST}$ の比較

図 $1 \mathrm{~A}, \mathrm{~B}$ のように $\mathrm{n}-\mathrm{ST}$ は, ST 上昇群 $8.1 \pm$ 2.4 , ST 非上昇群 $4.3 \pm 2.1 ， \Sigma-\mathrm{ST}$ は, ST 上昇群 $13.8 \pm 8.6 \mathrm{~mm}$, ST 非上昇群 $5.1 \pm 3.0 \mathrm{~mm}$ でいず れもST上昇群が有意に大きい值を示した（P< $0.01)$.

3 ）冠動脈造影所見の比較

表 2 のように器質的に有意狭窄を 1 枝以上認めた
症例は，ST 上昇群では $88.5 \%(62 / 70$ 例 $), S T$ 非 上昇群では $75 \%(112 / 150$ 例) であった. 1 枝病変 はST 上昇群が $14 \%(10 / 70$ 例) で, ST 非上昇群 では $61 \%(91 / 150$ 例）に比へ，有意に少なかった $(\mathrm{P}<0.01) .2$ 枝病変は ST 上昇群 $26 \%(18 / 70$ 例)，ST 非上昇群 $11 \%$ （16/150 例）で，ST上昇 群で有意に多くを占め $(\mathrm{P}<0.01)$, 特に「左前下行 枝十回旋枝」障害の組み合わせの例が有意に多かっ た $(\mathrm{P}<0.01)$ 。さらに 3 枝傷害および左主幹部病変 を合わせた多枝傷害例は，ST 上昇群では $48.5 \%$ (34/70 例), ST 非上昇群では 3\%（5/150 例） で著しい差を認めた $(\mathrm{P}<0.01)$.

4 ) ST 上昇群と非上昇群の院内心事故頻度

ST 上昇群では冠動脈バイパス術施行例が $31 \%$

表 1 患者背景・臨床所見-不安定狭心症例

\begin{tabular}{|c|c|c|c|}
\hline & $\mathrm{aVR}$ ST 上昇 $(70$ 例 $)$ & $a V_{R} S T$ 非上昇 (150 例) & \\
\hline 平均年齢 & 66 歳 & 61 歳 & $p<0.01$ \\
\hline 男性 & $48 \quad(69 \%)$ & $110(73 \%)$ & NS \\
\hline 高血圧 & $48 \quad(69 \%)$ & $92(61 \%)$ & NS \\
\hline 糖尿病 & $31(44 \%)$ & $48 \quad(32 \%)$ & NS \\
\hline 高脂血症 & $32(46 \%)$ & $76(51 \%)$ & NS \\
\hline 喫煙 & $35(50 \%)$ & $74 \quad(49 \%)$ & NS \\
\hline 心筋梗塞の既往 & $21 \quad(30 \%)$ & $30(20 \%)$ & NS \\
\hline $\begin{array}{c}\text { 不安定狭心症 } \\
\text { Braunwald 分類 } \\
\text { | / II/III } \\
\text { A / B / C }\end{array}$ & $\begin{array}{l}40 / 20 / 40(\%) \\
4 / 89 / 7(\%)\end{array}$ & $\begin{array}{l}30.5 / 20.5 / 49(\%) \\
3 / 91 / 6(\%)\end{array}$ & $\begin{array}{l}\text { NS/NS/NS } \\
\text { NS/NS/NS }\end{array}$ \\
\hline
\end{tabular}

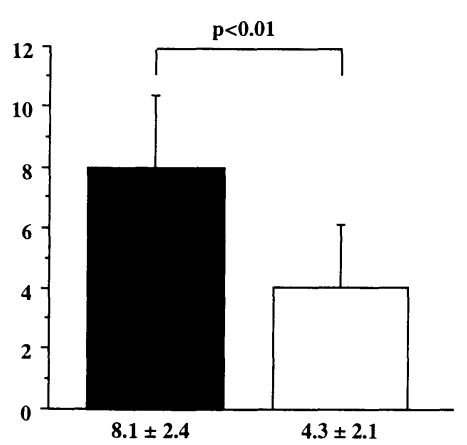

A ST 偏位誘導数 $(n-S T)$

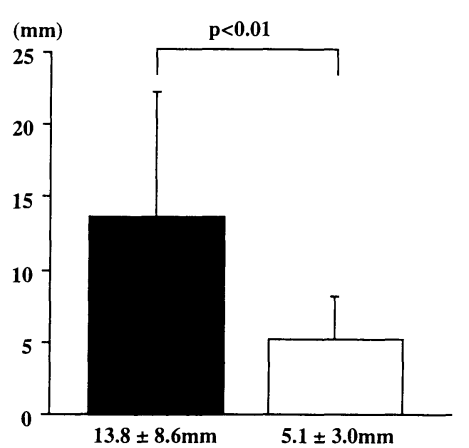

B ST 偏位絶対総量 $(\Sigma-S T)$

図 1 不安定狭心症例における胸痛発作時有意 ST 偏位誘導数 $(n-S T)$ と胸痛 発作有意 ST 偏位絶対総量 $(\Sigma-S T)$ 
表 $2 a V R$ 誘導 ST 上昇の有無による冠動脈病変数の比較-不安定狭心症例

\begin{tabular}{|c|c|c|c|}
\hline & 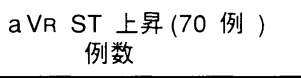 & $\begin{array}{l}\text { aVR ST 非上昇 (150 例) } \\
\text { 例数 }\end{array}$ & \\
\hline 有意狭窄なし & $8(11.5 \%)$ & $38 \quad(25.0 \%)$ & $p<0.01$ \\
\hline $\begin{array}{c}1 \text { 枝病変 } \\
\text { LAD } \\
\text { LCX } \\
\text { RCA } \\
2 \text { 枝病変 } \\
\text { LAD + LCX } \\
\text { LAD + RCA } \\
\text { LCX + RCA } \\
3 \text { 枝病変 }\end{array}$ & $\begin{array}{cc}10 \quad(14.0 \%) \\
4(5.5 \%) \\
2(3.0 \%) \\
4(5.5 \%) \\
\\
18 \quad(26.0 \%) \\
11(16.0 \%) \\
6(9.0 \%) \\
1(1.0 \%) \\
& (27.0 \%)\end{array}$ & $\begin{array}{cc}91 \quad(61.0 \%) \\
65(43.0 \%) \\
9(6.0 \%) \\
18(12.0 \%) \\
\\
16 \quad(11.0 \%) \\
4(2.5 \%) \\
5(3.5 \%) \\
7(5.0 \%) \\
\\
\\
3(2.0 \%)\end{array}$ & $\begin{array}{l}p<0.01 \\
p<0.01 \\
N S \\
N S \\
p<0.01 \\
p<0.01 \\
N S \\
N S \\
p<0.01\end{array}$ \\
\hline 左主幹部病変 & $15(21.5 \%)$ & $2(1.0 \%)$ & $p<0.01$ \\
\hline 1 枝病変以上 & $62(88.5 \%)$ & $112(75.0 \%)$ & $p<0.03$ \\
\hline 2 枝病変以上 & $52(74.5 \%)$ & $21(14.0 \%)$ & $p<0.01$ \\
\hline 3 枝病変以上 & $34(48.5 \%)$ & $5(3.0 \%)$ & $p<0.01$ \\
\hline
\end{tabular}

$L A D=$ 左前下行枝, $L C X=$ 左回旋枝, $R C A=$ 右冠動脈

表 3 患者背景・臨床所見-急性心筋梗塞例

\begin{tabular}{|c|c|c|c|}
\hline & $a V_{R} S T$ 上昇 $(72$ 例) & $\begin{array}{l}a V_{R} S T \text { 非上昇 (413 例) } \\
\text { 例数 }\end{array}$ & \\
\hline 平均年齢 & 68 & 63 & $p<0.01$ \\
\hline 男性 & $45(63 \%)$ & $310(75 \%)$ & $p<0.05$ \\
\hline 高血圧 & $51(71 \%)$ & $244(59 \%)$ & NS \\
\hline 糖尿病 & $35(49 \%)$ & $147(36 \%)$ & $p<0.05$ \\
\hline 高脂血症 & $18(25 \%)$ & $150(36 \%)$ & NS \\
\hline 喫煙 & $32(45 \%)$ & $273(66 \%)$ & $p<0.01$ \\
\hline $\begin{array}{l}\text { 心筋梗塞の既往 } \\
\text { Killip 分類： }\end{array}$ & $22(31 \%)$ & $37(9 \%)$ & $p<0.01$ \\
\hline $\mathrm{I}(\%)$ & $30(42 \%)$ & $330(80 \%)$ & $\mathrm{p}<0.01$ \\
\hline$\|(\%)$ & $9(13 \%)$ & $30(7 \%)$ & NS \\
\hline III(\%) & $13(18 \%)$ & $23(6 \%)$ & $p<0.01$ \\
\hline $\mathrm{IV}(\%)$ & $20(27 \%)$ & $30(7 \%)$ & $p<0.01$ \\
\hline 左室駆出率 (\%) & $40 \pm 16$ & $48 \pm 14$ & $p<0.01$ \\
\hline Peak CPK值 (U/l) & $3540 \pm 4451$ & $2908 \pm 2475$ & NS \\
\hline
\end{tabular}

(22/70 例)，急性心筋梗塞移行例 $19 \%$ (13/70 例), 院内死亡例が $5 \%$ （7／150 例）であったのに 対し, ST非上昇群ではそれぞれ $1 \%$ （2/150 例)，8\%(12/150 例)，1\%（2/150 例)，いず れの事象もST 上昇群で有意に高い頻度であった $(\mathrm{P}<0.01)$.

\section{2. 急性心筋梗塞の成績}

1) 患者背景・臨床所見および経過

表 3 に示すようにST 上昇群が ST 非上昇群に比
べ，年齢は有意に高く，女性の比率が有意に多かっ た。また糖尿病，心筋梗塞の既往例は，ST 上昇群に 有意に多かったが，喫煙は ST 非上昇群に有意に多 かった。重症ポンプ不全症例（Killip III群とIV群） が，ST 非上昇群では $13 \%(53 / 413$ 例)であったの に対し，ST 上昇群では $45 \%$ (33/72 例) と極めて 高い值を示した。なお，Killip I 群はST 上昇群が 非上昇群に比べ有意に少なかった $(\mathrm{P}<0.01)$. 左室 駆出率は, ST 上昇群 $40 \pm 16 \%$ に対し, ST 非上昇群 
$48 \pm 14 \%$ で，ST 上昇群が有意に低值であった $(\mathrm{P}<$ 0.01). Peak CPK 值は両群間に有意差はなかった が ST 上昇群に高い傾向にあった。

\section{2 ）冠動脈造影所見の比較}

表 4 に示すように 1 枝以上に有意狭窄を認めた症 例は，ST 非上昇群では $96 \%$ (69/72 例)，ST 非上 昇群では $94 \%$ （390／413 例）で，同頻度であった。 1 枝病変は ST 上昇群 $17 \%$ (12/72 例), ST 非上昇
群では $73 \%$ (301／413 例）に認められ，ST 上昇群 で有意に少なかった $(\mathrm{P}<0.01) .2$ 枝病変は ST 上 昇群 $20 \%$ (15/72 例), ST 非上昇群 $15 \%$ (62/413 例)で, 両群に有意の差はなかったが, ST 上昇群で 「左前下行枝十回旋枝」障害例が有意に多かった $(\mathrm{P}<0.03) .3$ 枝病変および左主幹部病変を認める 多枝冠動脈障害症例は, ST 上昇群 $59 \%$ (42/72 例) に認め，ST 非上昇群では $6 \%(27 / 413$ 例）と比較

\section{表 $4 a \mathrm{a} R$ 誘導 ST 上昇の有無による冠動脈病変数の比較-急性心筋梗塞}

\begin{tabular}{|c|c|c|c|}
\hline & $a V_{R} S T$ 上昇 $(72$ 例 $)$ & $\begin{array}{l}a V_{R} S T \text { 非上昇 (413 例) } \\
\text { 例数 }\end{array}$ & \\
\hline 有意狭窄なし & $3(4.0 \%)$ & $23(6.0 \%)$ & NS \\
\hline $\begin{array}{c}1 \text { 枝病変 } \\
\text { LAD } \\
\text { LCX } \\
\text { RCA } \\
2 \text { 枝病変 } \\
\text { LAD + LCX } \\
\text { LAD + RCA } \\
\text { LCX + RCA } \\
3 \text { 枝病変 }\end{array}$ & 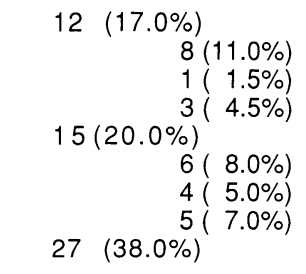 & $\begin{array}{c}301(73.0 \%) \\
173(42.0 \%) \\
26(6.0 \%) \\
102(25.0 \%) \\
62 \quad(15.0 \%) \\
11(3.0 \%) \\
37(8.0 \%) \\
17(4.0 \%) \\
19(5.0 \%)\end{array}$ & $\begin{array}{l}p<0.01 \\
p<0.01 \\
N S \\
p<0.01 \\
p<0.01 \\
p<0.03 \\
N S \\
N S \\
p<0.01\end{array}$ \\
\hline 左主幹部病変 & $15(21.0 \%)$ & $8 \quad(2.0 \%)$ & $p<0.01$ \\
\hline 1 枝病変以上 & 69 (96.0\%) & $390 \quad(94.0 \%)$ & NS \\
\hline 2 枝病変以上 & $57(79.0 \%)$ & $89(21.0 \%)$ & $p<0.01$ \\
\hline 3 枝病変以上 & $42(59.0 \%)$ & 27 ( $6.0 \%)$ & $p<0.01$ \\
\hline
\end{tabular}

$L A D=$ 左前下行枝, $L C X=$ 左回旋枝, $R C A=$ 右冠動脈

表 5 諸臨床所見における 3 枝・左主幹部病変に対する相対危険度

\begin{tabular}{|c|c|c|c|c|c|}
\hline & & 不安定狭心症 & 危険率 & 急性心筋梗塞 & 危険率 \\
\hline 年齢 & $\frac{65 \text { 以上 }}{65 \text { 未满 }}$ & $\frac{26 / 97(27)}{12 / 124(10)}$ & 1.0 & $\frac{45 / 242(19)}{22 / 243(9)}$ & 1.6 \\
\hline 性 & $\frac{\text { 女 }}{\text { 男 }}$ & $\frac{10 / 61(16)}{28 / 160(18)}$ & 0.7 & $\frac{21 / 131(16)}{46 / 354(13)}$ & 0.8 \\
\hline 高血压 & $\begin{array}{l}\text { あり } \\
\text { なし }\end{array}$ & $\frac{28 / 140(20)}{10 / 81(12)}$ & 1.3 & $\frac{49 / 295(17)}{18 / 190(9)}$ & 1.4 \\
\hline 糖尿病 & $\frac{\text { あり }}{\text { なし }}$ & $\frac{16 / 79(20)}{22 / 142(15)}$ & 1.2 & $\frac{37 / 182(20)}{30 / 303(10)}$ & 1.5 \\
\hline 高脂血症 & $\frac{\text { あり }}{\text { なし }}$ & $\frac{15 / 108(14)}{23 / 113(20)}$ & 0.7 & $\frac{21 / 168(13)}{46 / 317(15)}$ & 1.1 \\
\hline 喫煙 & $\frac{\text { あり }}{\text { なし }}$ & $\frac{19 / 110(17)}{19 / 111(17)}$ & 1.0 & $\frac{33 / 306(11)}{34 / 179(19)}$ & 1.0 \\
\hline 心筋梗塞の既往 & $\frac{\text { あり }}{\text { なし }}$ & $\frac{15 / 51(29)}{23 / 170(14)}$ & 1.5 & $\frac{17 / 59(29)}{50 / 426(12)}$ & 1.1 \\
\hline $\begin{array}{l}\text { 不安定狭心症 } \\
\text { Braunwald 分類 }\end{array}$ & $\frac{111}{1, \|}$ & $\frac{15 / 107(14)}{23 / 114(20)}$ & 0.9 & $\cdots$ & --- \\
\hline Killip 分類 III • IV & $\frac{\mathrm{II}, \mathrm{IV}}{\mathrm{I}, \mathrm{II}}$ & --- & $\cdots$ & $\frac{32 / 85(38)}{35 / 400(9)}$ & $2.1^{* *}$ \\
\hline$a V_{R}$ 上昇 & $\begin{array}{l}\text { あり } \\
\text { なし }\end{array}$ & $\frac{33 / 70(47)}{5 / 151(3)}$ & $11.4^{*}$ & $\frac{40 / 71(56)}{27 / 414(7)}$ & $5.8^{*}$ \\
\hline
\end{tabular}


表 $6 a V_{R}$ 誘導 $S T$ 上昇による急性冠症候群の 冠動脈多枝障害（3 枝・左主幹部）の推定

\begin{tabular}{lcc}
\hline & 不安定狭心症 & 急性心筋梗塞 \\
\hline 感度 & $87 \%$ & $61 \%$ \\
特異度 & $80 \%$ & $93 \%$ \\
的中率 & $81 \%$ & $88 \%$ \\
予測率 & & \\
陽性 & $49 \%$ & $58 \%$ \\
陰性 & $97 \%$ & $93 \%$ \\
\hline
\end{tabular}

して有意に多い值を示した $(\mathrm{P}<0.01)$.

3 ） ST 上昇例と非上昇例の院内心事故頻度

$\mathrm{ST}$ 上昇を示した 72 例のうち冠動脈バイパス術 施行例は $26 \%$ (19/72 例), 院内死亡例は $31 \%$ (22/72 例) であったが，ST 非上昇群 (413 例) で はそれぞれ $4 \%$ (17/413 例)，6\%（24/413 例) を示し，いずれにおいてもST 上昇群で有意に高い 頻度であった $(\mathrm{P}<0.01)$.

\section{3. 諸臨床所見の 3 枝・左主幹部病変に対する 相対危険度}

表 5 のように UAP 例では $\mathrm{aVR}$ 誘導 $\mathrm{ST}$ 上昇の 所見のみが有意な危険因子であった $(\mathrm{P}<0.001)$. AMI 例では Killip 分類III群・IV 群の存在と $\mathrm{aVR}$ 誘 導の ST 上昇所見が有意な危険因子であった（P< $0.005, \mathrm{P}<0.001)$.

\section{4. $\mathrm{a} \mathrm{V}_{\mathrm{R}} \mathrm{ST}$ 上昇による冠動脈障害枝数の推定 \\ 1) 3 枝・左主幹部障害の推定}

表 6 に示すように感度, 特異度および的中率は, UAP 群が $87 \%$, $80 \%$ ，81\%, AMI 群が $61 \%$, 93 \%, $88 \%$ で，陽性予測率および陰性予測率は UAP 群が 49 \%，97\%，AMI 群 58 \%，93\%を示した。

\section{2 ） 2 枝以上の多枝冠動脈障害の推定}

表 7 に示すように感度, 特異度および的中率は, UAP 群が 71 \%, 88 \%, 82\%, AMI 群が $39 \%$, 96 \%，79\%であった。陽性予測率および陰性予測率は UAP 群が $74 \%, 86 \%$, AMI 群が $79 \%, 78 \%$ を示 した.
表 $7 \mathrm{aVR}$ 誘導 ST 上昇による急性冠症候群の 冠動脈多枝障害 $(2,3$ 枝・左主幹部) の推定

\begin{tabular}{lcc}
\hline & 不安定狭心症 & 急性心筋梗塞 \\
\hline 感度 & $71 \%$ & $39 \%$ \\
特異度 & $88 \%$ & $96 \%$ \\
的中率 & $82 \%$ & $79 \%$ \\
予測率 & & \\
陽性 & $74 \%$ & $79 \%$ \\
陰性 & $86 \%$ & $78 \%$ \\
\hline
\end{tabular}

以上より，3枝・左主幹部病変に加え 2 枝を含め ると, 陰性予測率の大きな変化なしに陽性予測率が 高くなることが示された.

\section{IV. 考察}

重症多枝冠動脈障害は予後不良な病態であるため, その診断は極めて重要な意義をもつ. 古くから冠動 脈造影以外の方法を用いてかかる冠動脈障害を予測 する試みがなされている。

Plotnick ら ${ }^{15)}$ は, 不安定狭心症において左主幹部 病変を予測し得る臨床所見を検討した結果, 増悪型 狭心症状の存在, 胸痛時, 前壁誘導である第 I, $\mathrm{aVL}, \mathrm{V}_{1} \sim \mathrm{V}_{4}$ と下壁誘導である第 II, 第 III, $\mathrm{aVF}$ の ST 低下, 透視下の左主幹部の石圧化をあげたが, 予 測率はいずれも低く，同病態を臨床所見のみで確実 に予測することは困難であって, 冠動脈造影施行が 望ましい，と結論している.

Maddahi ${ }^{16)} ら$, Bodenheimer $ら^{17)}$ は, 虚血性心疾 患の 3 枝および左主幹部病変の同定を負荷心筋夕り ウムシンチグラムを行って検討したが，同検査のみ では感度の点で不十分であり, 運動負荷心電図と併 用すると高い感度を得られる，と結論している。ま た多段階運動負荷心電図試験における ST/HR Slop ${ }^{18,19)}$, ST/HR Index ${ }^{20)}$ 等の新しい指標が高感度 に多枝冠動脈障害を判定できるとする報告もある.

しかし, 迅速な早期診断が必要とされる急性冠症 候群においては運動負荷試験や心筋シンチグラム等 
の検査施行はほぼ不可能であり，早期かつ的確な診 断は，冠動脈造影によらざるをえないのが現状であ $ろ^{15)}$.

ところで $\mathrm{aVR}$ 誘導は, 心臓の長軸方向からみた左 右心室内腔の電気現象を反映しており, 心筋層の心 内膜側に広範な虚血が生じた場合にその ST 部分が 上昇すると考えられ, 心内膜下梗塞の重要な心電図 所見のひとつである ${ }^{8,9,11)}$. 心内膜下梗塞は, 円周状あ るいは半円周状の広範囲にわたり心内膜層が一様に 傷害を受けるものであり ${ }^{8,9)}$, 冠動脈造影ではその半 数以上の症例で多枝冠動脈障害がみられると報告さ れている7). 病理学的には “balanced stenosis”, “proximal location”を特徵とする冠動脈病変を呈 するとされる ${ }^{21)}$.すなわち 3 枝の近位部に一様に狭 窄が進行することにより, 心筋庇護に必要な側副血 行路が形成されにくく，その結果広範な心内膜下の 心筋傷害壊死を生ずるとされている. Madigan ら ${ }^{11)}$ は, 心内膜下梗塞 50 例の冠動脈造影所見について検 討した結果， 2 枝以上に狭窄を認めるいわゆる多枝 冠動脈障害の割合は $60 \%$ （30/50 例）であったと し, 本症は多枝病変を有することが多いので, 厳重 な管理下にて治療と早期の冠動脈造影を施行すべき であると報告している。

以上の背景より著者らは, $\mathrm{aVR}$ 誘導の $\mathrm{ST}$ 上昇所 見は, 心内膜下梗塞に限らず，他の重症多枝冠動脈 障害の指標になりうると考え, 不安定狭心症と急性 心筋梗塞における $\mathrm{aVR}$ 誘導 $\mathrm{ST}$ 上昇と冠動脈造影 所見の関連を調べ，その臨床的意義について検討し た.その結果, 不安定狭心症では冠動脈造影を施行 例中, $\mathrm{aVR}$ の有意な $\mathrm{ST}$ 上昇が $32 \%$ にみれ，その うち左主幹部病変を含めた 2 枝以上の多枝冠動脈障 害例が $74.5 \%$ に認められ, 急性心筋梗塞移行率や院 内死亡率も非上昇例に比べ明らかに高かった。一方， 急性心筋梗塞では, $\mathrm{aVR}$ の有意な ST 上昇を認めた のは $15 \%$ で，そのうち多枝冠動脈障害は $79 \%$ にみ られ, $\mathrm{aVR}$ 非上昇例と比較して, 収容時重症ポンプ 不全 (Killip III・IV群) の合併率が, 有意に高く, 左 室駆出率が有意に低值で, 院内死亡率が高率であっ
た。すなわち， $\mathrm{aVR}$ 誘導の $\mathrm{ST}$ 上昇は多枝冠動脈障 害の存在を示し，予後不良の所見と結論された。

ところで心電図から多枝冠動脈障害を予測する試 みは既にいくつかなされている. ST 偏位のみによ る検討では, 不安定狭心症患者の胸痛発作時 ${ }^{22}$, 運動 負荷試験時 ${ }^{23,24)}$ のいずれにおいても，3枝および左 主幹部病変例は 1,2 枝病変症例に比し有意に大で あり, 重症冠動脈障害の最も強い予測因子であると 報告されている，著者らの成績でもほぼ同様な結果 であり，aVR 上昇例における $\mathrm{n}-\mathrm{ST}, \Sigma-\mathrm{ST}$ は, 非上 昇例に比し，明らかに大であり，しかも 2 枝以上の 多枝冠動脈障害が多かった。

Brugada ら ${ }^{25)}$ は, 左主幹部病変例では胸痛発作時 に胸部誘導 $V_{4} \sim V_{6}$ のST 低下と第 $\mathrm{I}$ 誘導, $a V_{R}$ の $\mathrm{ST}$ 上昇が主な所見としてみられると述べ, Gorgels $ら^{26)}$ は, 安静狭心症 113 例の虚血発作時心電図所見 を検討した結果, 左主幹部病変, 3 枝障害の症例に おいては発作時第 $I$, 第 II 誘導, $V_{4} \sim V_{6}$ 誘導の ST 低下のほか $\mathrm{aVR}$ の ST 上昇が重要な所見としてみ られるとしている。いずれも $\mathrm{aVR}$ の変化については 著者らと同様な見解である.さらに彼ら ${ }^{26)}$ は, 発作時 第 I 誘導, $a V R$ の $\mathrm{ST}$ 上昇ともに第 $\mathrm{I}$ 誘導, $\mathrm{V}_{4} \sim \mathrm{V}_{6}$ 誘導のST 低下の所見を認めた場合の, 左主幹部, 3 枝病変例の陽性予測率および陰性予測率はそれぞれ $62 \%, 78 \%$ と報告している. $\mathrm{aVR}$ のみを用いて不安 定狭心症例における ST 上昇の意義を検討した著者 らの成績では 3 枝・左主幹部障害の陽性予測率およ び陰性予測率はそれぞれ $49 \%, 97 \%$ \%あり, 彼らの 結果と比べ特異度は高いものの陽性予測率は低值で あった。しかし 2 枝病変以上の検出を目的にすると， その陽性予測率は $74 \%$ と高くなった。この理由とし て, 著者らの成績では $\mathrm{aVR}$ 上昇例に 2 枝病変例が多 く含まれていることが考えられる，2枝病変例の内 訳を詳細に検討すると $60 \%$ 以上が「左前下行枝十回 旋枝」障害の組み合わせであった。左前下行枝と回 旋枝近位部の両方に有意狭窄を認める場合は, “Left main equivalent coronary artery disease $(\mathrm{LMQD})$ ”と称され, 左主幹部病変と同等の臨床的 
意義を有するとされる. 左主幹部病変に比べ, 予後 は比較的悪くはないとされている ${ }^{27,29)}$ が, 他の 2,3 枝病変に比べ死亡率が高いと報告されている ${ }^{30)}$.す なわち, LMQD は左主幹部病変に近似した病態であ ると考えられる。したがって，この検出も臨床的に 重要な意義があり, aVR の ST 上昇単独での評価は 3 枝, 左主幹部病変のみならず, LMQD をも検出可 能である.

著者らの $\mathrm{aVR}$ についての検討では不安定狭心症 例において左室領域に広範な虚血が生じたかの判定 に有用であったが, 急性心筋梗塞例では冠動脈病変 に対する感度がやや低く, 特異度は高かった。その 理由として, 不安定狭心症例と急性心筋梗塞例の $\mathrm{aVR}$ 上昇例出現頻度に差があり, 不安定狭心症例で $\mathrm{a} V \mathrm{R}$ 上昇例出現率は $32 \%(70 / 220$ 例 $)$, 急性心筋梗 塞例で $15 \%$ (72/485 例) と急性心筋梗塞例で $\mathrm{aVR}$ 上昇例出現頻度が有意に少なかった $(\mathrm{p}<0.01)$.こ のことから急性心筋梗塞例で $\mathrm{aVR}$ 誘導 $\mathrm{ST}$ 上昇の 偽陰性例が多く, その結果, 感度が低く, 特異度が 高い結果となったと考えられる，偽陰性例が多い理 由として急性心筋梗塞は, 多くは貫壁性の心筋虚血 が局所に確立しており, 一様な心内膜下の虚血が標 準四肢 $\mathrm{aVR}$ 誘導 ST 上昇に反映しにくかったと考 えられた。

以上より, $\mathrm{aVR}$ 誘導 $\mathrm{ST}$ 上昇は, 急性冠症候群, 特に不安定狭心症において左冠動脈を主体とした多 枝冠動脈障害を迅速かつ簡便に診断できる臨床的に 極めて有用な指標と結論される.

(本論文の要旨は第 12 回日本心電学会学術集会に て発表した。）

\section{〔文献〕}

1) Goldberg RJ, Gore JM, Alpert JS, Osganian V, de Groot J, Bade J, Chen Z, Frid D, Dalen JE : Cardiogenic shock after acute myocardial infarction. Incidence and mortality from a community-wide perspective, 1975 to 1988. N Engl J Med 325 : 1117, 1991
2 ) Gazes PC, Mobley EM, Faris HE, Duncan RC, Humphries GB : Preinfarction (unstable) angina-A prospective study-Ten years follow-up. Prognostic significance of electrocardiographic changes. Circulation 48 : 331, 1973

3 ) Fuster V, Badimon L, Badimon JJ, Cheserbro JH : The pathogenesis of coronary artery desease and the acute coronary symdromes. (First of two parts). N Engl J Med 23 : 242, 1992

4) Proudfit WL, Bruschke AVG, Sones FM : Natural history of obstructive coronary artery disease : Tenyears study of 601 nonsurgical cases. Prog Cardiovasc Dis $21: 53,1978$

5) Harris PJ, Phil D, Harrll FE, Lee KL, Behar VS, Rosati RA : Survival in medical treated coronary artery disease. Circulation $60: 1259,1979$

6 ) Bruschke AVG, Proudfit WL, Sones FM : Progress study of 590 consecutive nonsurgical cases of coronary disease followed 5-9 years. I. Arteriographic correlations. Circulation $47: 1147,1973$

7 ) Mock MB, Ringqvist I, Fisher LD, Davis KB, chaitman BR, Kouchoukos NT, Kaiser GC, Alderman E, Ryan TJ, Russell RO, Mullin S, Fray D, Killip T, and participants in the coronary artery surgery study : Survival of medically treated patients in the coronary aftery surgery study (CASS) registry. Circulation 66 : 562, 1982

8 ) Cook RW, Edwards JE, Pruitt RD : Electrocardiographic changes in acute subendocardial infarction. I. Large subendocardial and large nontransmuralinfarcts. Circulation $18: 603,1958$

9) Georas CS, Dahlquist E, Cutts FB : Subendocardial infarction. Correlation of clinical, electrocardiographic, and pathologic data in 17 cases. Arch Intrn Med $111: 488,1963$

10) Levine HD, Ford RV : Subendocardial infarctionReport of six cases and critical survey of the literature-. Circulation $1: 246,1950$

11) Madigan NP, Rutherford BD, Frye RL : The clinical course, early prognosis and coronary anatomy of subendocardial infarction. Am J Med $60: 634,1976$

12) Braunwald $E$ : Unstable angina : a classification. Circulation $80: 410,1989$

13) Plotnick G, Conti CR : Transient ST-segment elevation in unstable angina: Clinical and hemodynamic significance. Circulation $51: 1015,1975$

14) ST John Sutton M, Pfeffer MA, Plappert T, Rouleau JL, Moye LA, Dagenais GR, Lamas GA, Klein M, Sussex B, Goldman S, Menapace FJ, Parker JO, Lewis S, Sestier F, Gordon DF, McEwan P, Bernstein 
V, Braunwald E, for SAVE Investigation. Quantitative two-dimensional echocardiographic measurements are major predictors of adverse cardiovascular events after acute myocardial infarction : the protective effect of captopril. Circulation $89: 68,1994$

15) Plotnick GD, Greene HL, Carliner NH, Becker LC, Fisher ML : Clinical indicators of left main coronary aftery disease in unstable angina. Ann Int Med 91 : 149, 1979

16) Maddahi J, Abdulla A, Garcia EV, Swan HJC, Berman DS : Noninvasive identification of left main and triple vessel coronary artery disease : Improved accuracy using quantitative analysis of regional myocardial stress distribution and washout of thallium-201. J Am Coll Cardiol 7 : 53, 1986

17) Bodenheimer MM, Banka VS, Fooshee CM, Helfant $\mathrm{RH}$ : Comparative sensitivity of the exercise electrocardiogram, thallium imaging and stress radionuclide angiography to detect the presence and severity of coronary heart disease. Circulation 60 : 1270, 1979

18) Elamin MS, Mary DASG, Smith DR, Linden RJ : Prediction of severity of coronary artery disease using slop of submaximal ST segment/heart rate relationship. Cardiovasc Res 14 : 681, 1980

19) Okin PM, Kligfield P, Ameisen O, Goldberg HL, Borer JS : Identification of anatomically extensive coronary artery disease by the exercise ECG ST segment/heart rate slop. Am Heart J 115 : 1002, 1988

20) Bobbio M, Detrano R, Schmid JJ, Janosi A, Righetti A, Pfisterer M, Steinbrunn W, Guppy KH, AbiMansour P, deckers JW, Colombo A, Lehmann KG, Olson HG : Exercise-induced ST depressin and ST/ heart rate index to predict triple-vessel or left main coronary disease : A multicenter analysis. J Am Coll Cardiol $19: 11,1992$

21) Sugiura M, Okada R, Iizuka $H$ : A clinicopathlogical study on subendocardial infarction in the aged. Jap Heart J 10 : 203 217, 1969

22) Papapietro SE, Niess GS, Paine TD, Mantle JA, Rackley CE, Russell RO, Rogers WJ : Transient electrocardiographic changes in patients with unsta- ble angina: Relation to coronary arterial anatomy. Am J Cardiol 46 : 28, 1980

23) Cheitlin MD, Davia JE, de Castro CM, Barrow EA, Anderson WT : Correlation of "critical" left coronary artery 1; esions with positive submaximal exercise tests in patients with chest pain. Am Heart J 89 : 305, 1975

24) Ribisl PM, Morris CK, Kawaguchi T, Ueshima K, Froelicher VF : Angiographic patterns and severe coronary artery disease. Exercise test correlates. Arch Intern Med 152 : 1618, 1992

25) Brugada JAT, Brugada J, Smeets LRM, Cruz FE, Roukens PR, Gorgels APM, Bar FWHM, Wellens HJJ : Clinical presentation and prognosis of left main coronary artery in the 1980s. Eur Heart J 12 : 495, 1991

26) Gorgels APM, Vos MA, Mulleneer R, de Zwaan C, Bär FWHM, Wellens HJJ : Value of the electrocardiogram in diagnosing the number of severely narrowed coronary arteries in angina pectoris. Am J Cardiol 72 : 999, 1993

27) Babb JD, Schmidt RG, Berard TM, Field JM : Clinical featere of left main equvalent coronary disease. Am J Cardiol $45: 222,1980$

28) Chaitman BR, Davis K, Fisher LD, Bourassa MG, Mock MB, Lesperance J, Kiloip T, for the Participating CASS Hospitals. A life table and coronary regression analysis of patients with combined proximal left anterior descending and proximal left circumflex coronary artery disease : non-left main equivalent lesion (CASS). Circulation $68: 1163,1983$

29) Caracciolo EA, Davis KB, Sopko G, Kaiser GC, Corly SD, Schaff H, Taylor HA, Chaitman BR, for the CASS investigaors. Comparison of surgical and medical group survival in patients with left main equivalent coronary artery disease. Longterm CASS experience. Circulation 91 : 2335, 1995

30) Califf RM, Conley MJ, Behar VS, Harrell FE Jr, Lee KL, Pryor DB, McKinnis RA, Rosati RA : "Left main equivalent" coronary disease : its clinical presentation and prognostic significance with nonsurgical therapy. Am J Cardiol 53 : 1489, 1984 